\title{
Tandem Standard-Size and ("Diagnostic") Ultra-Slim Cholangioscopy to Guide and Validate Completeness of Mechanical Lithotripsy
}

\author{
Vincent Zimmer ${ }^{\mathrm{a}, \mathrm{b}}$

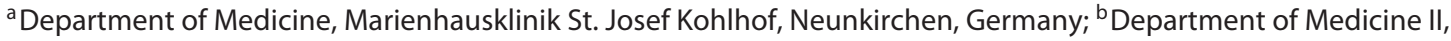 \\ Saarland University Medical Center, Saarland University, Homburg, Germany
}

Keywords

Complex bile duct stone disease - Endoscopic retrograde cholangiopancreatography · Cholangioscopy · Endoscopy · Cholecystectomy $\cdot$ Lithotripsy

\section{Colangioscópio de tamanho convencional e extra- fino ("diagnóstico") em tandem para guiar e validar a plenitude da litotripsia mecânica}

\section{Palavras Chave \\ Colangioscópio · Colecistectomia · Litíase biliar complexa $\cdot$ Colangiopancreatografia retrógrada endoscópica · Endoscopia · Litotripsia}

An 86-year-old patient with a prior history of cholecystectomy was referred for endoscopic retrograde cholangiopancreatography (ERCP) due to stone-related cholangitis. At the index ERCP, biliary drainage using a 10-Fr double-pigtail stent was established after limited papillotomy. Repeat ERCP including adequate contrast application indicated marked biliary dilation with distal tapering and $>8$ large, partly barrel-shaped stones $>15$ mm (Fig. 1a). After 2 ERCP sessions including largeballoon dilation to $13.5 \mathrm{~mm}$, and multiple mechanical lithotripsies (MLs), the biliary stone burden was markedly diminished. However, a smooth distal tapering of the distal common bile duct (CBD), most likely attributable to high mechanical stress from multiple stone and/ or ML fragment extractions, emerged at the 3rd ERCP, with a remaining large stone detected above the relative stricture. Given the transient unavailability of electrohydraulic lithotripsy (EHL) at our institution, we opted for standard-size direct cholangioscopy ([DC], outer-scope diameter $9.8 \mathrm{~mm}$ and working-channel $2.8 \mathrm{~mm}$ ) after freehand intubation to cope with failed stone capture by conventional ERCP technology as a sine qua non for proceeding with ML. Direct endoscopic visualization likewise replicated a scarred, unpassable bile duct stricture with visible stone material higher in the CBD (Fig. 1b). Under endoscopic vision, a rotable retrieval basket was introduced and the stone was successfully grasped (Fig. 1c). Next, ML, using a rescue lithotripter, was performed under fluoroscopic guidance (Fig. 1d). This was followed by the flushing out and extraction of some smaller ML fragments, and a final "diagnostic" ul- karger@karger.com www.karger.com/pjg

Karger $\stackrel{\text { '⿳亠丷厂 }}{ }$ BOPEN ACCESS
C 2021 Sociedade Portuguesa de Gastrenterologia. Published by S. Karger AG, Basel

This is an Open Access article licensed under the Creative Commons Attribution-NonCommercial-4.0 International License (CC BY-NC) (http://www.karger.com/Services/OpenAccessLicense), applicable to the online version of the article only. Usage and distribution for commercial purposes requires written permission. 


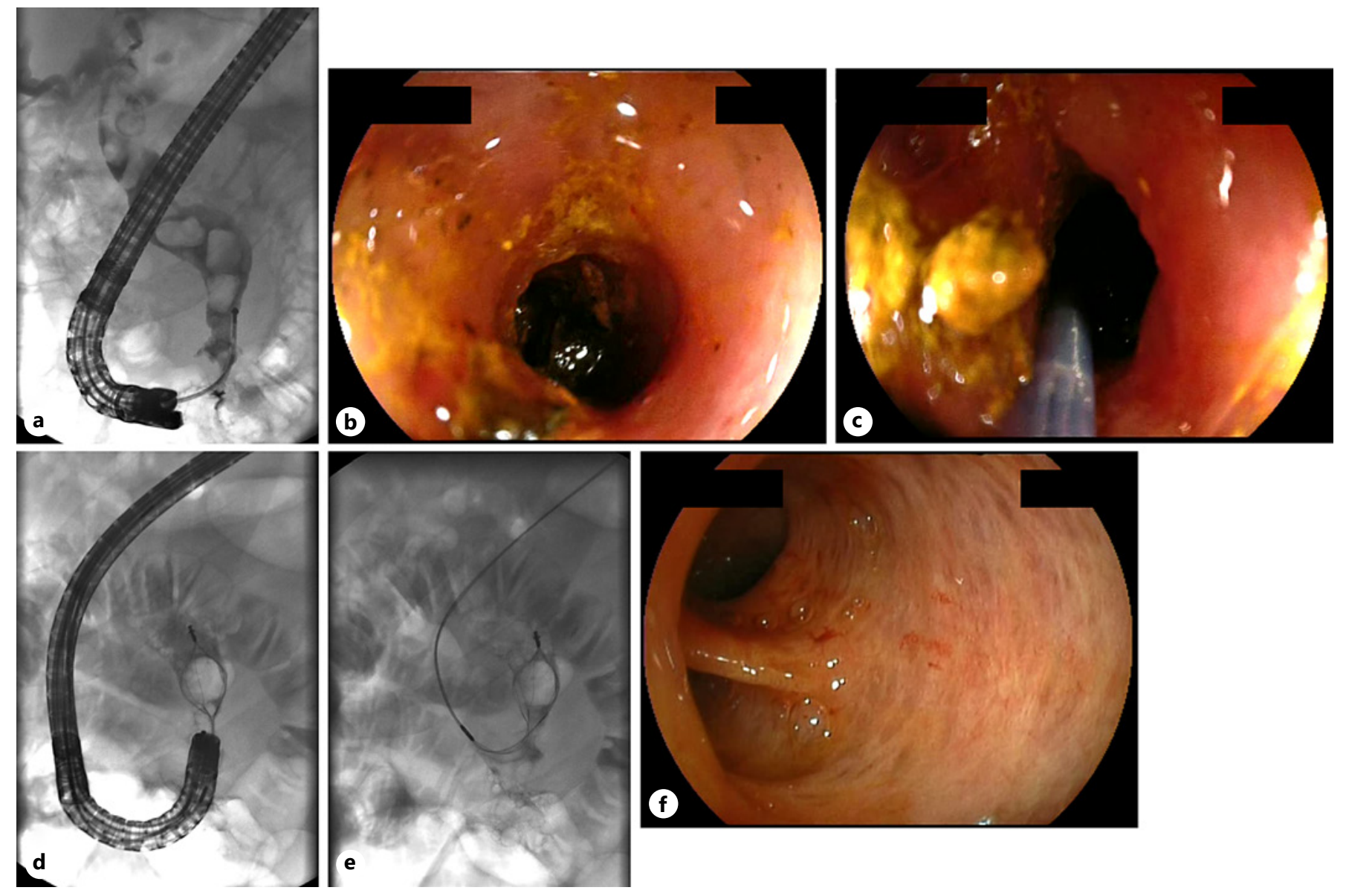

Fig. 1. a Initial cholangiography indicating diffuse bile duct dilation with extensive stone burden. b Direct cholangioscopy (DC), using a standard-size upper endoscope with a 2.8 -mm working channel sufficient to accommodate conventional ERCP devices, demonstrating a scarred stricture with a large residual stone above. c Successful cholangioscopy-guided capture using a rotableDormiabasketwithhigh-expansionforces(twist'n'CATCH ${ }^{\circledR}$,

tra-slim DC (outer diameter $5.9 \mathrm{~mm}$; working channel $2.0 \mathrm{~mm}$ ) able to pass the stricture excluded remnant biliary stone disease throughout the biliary system (Fig. 1e). Of note, given the known lack of sensitivity to exclude remnant stone disease on cholangiography in the presence of diffuse bile duct dilation, cholangioscopic confirmation of freedom from stones might be implemented on a low-threshold basis; a recent small-scale study indicated detection of residual stones in $>20 \%$ of patients [1].

Tandem approaches in DC, relying on standard-size (a large-capacity working channel able to accept standard ERCP equipment) followed by ("diagnostic") ultra-slim scope technology, are rarely considered in clinical prac-
Medwork, Höchstadt/Aisch, Germany; d) as confirmed by fluoroscopy. e Uncomplicated mechanical lithotripsy (ML) above the stricture, with bile duct clearance by subsequent flushing out and/or extraction of ML fragments. f Freedom from residual bile duct stone disease finally confirmed by repeat "diagnostic" DC, using an ultra-slim upper endoscope able to pass the benign stricture. tice [2]. Notwithstanding, as is illustrated in this unique clinical report, tandem cholangioscopy can add to the endoscopic armamentarium in complex biliary diseases in highly selected cases.

\section{Statement of Ethics}

The patient gave written informed consent for publication (including publication of images).

\section{Conflict of Interest Statement}

The authors have no conflicts of interest to declare. 
Funding Sources

References

There was no funding.

\section{Author Contributions}

V.Z.: clinical care and drafting and finalization of the paper.
1 Anderloni A, Auriemma F, Fugazza A, Troncone E, Maia L, Maselli R, et al. Direct peroral cholangioscopy in the management of difficult biliary stones: a new tool to confirm common bile duct clearance. Results of a preliminary study. J Gastrointestin Liver Dis. 2019 Mar;28(1):89-94.

2 Zimmer V, Lammert F. A "tandem approach" using sequential diagnostic (ultraslim) and therapeutic (standard size) direct freehand cholangioscopy to guide mechanical lithotripsy of a giant cystic duct remnant stone. Endoscopy. 2017 Jun;49(6):E160-2. 